\title{
Program Lansia Sabar Berbasis Reminiscence dan Terapi Seni untuk Menurunkan Kecemasan pada Lansia Penyandang Diabetes Melitus Tipe II
}

\author{
Errina Puspitasari ${ }^{1} \mathcal{E}$ Sofia Retnowati ${ }^{2}$ \\ Fakultas Psikologi Universitas Gadjah Mada
}

\begin{abstract}
This "Lansia Sabar" program which is consisted of reminiscence and art therapy is expected to facilitate the elderly to look back on their lives positively. This programm was administered to nine (9) elderly with type II diabetes mellitus aged 55-70 years who show moderate to severe levels of anxiety. Anxiety level is measured using Beck Anxiety Inventory (BAI). The program lasts for six meetings with a maximum duration of 120 minutes for each session. The experimental design using one-group pretest-posttest with additional double pretest. Data will be analyzed quantitatively using the friedman test, with the additional descriptive data analysis on the results of observation, task book, and the visual inspection. The Friedman test showed $\mathrm{F}_{\mathrm{r}(2)}=5,200, \mathrm{p}=0,074(\mathrm{p}>0,05)$. It showed that "Lansia Sabar" program has no significant effect to decrease anxiety in the elderly with type II diabetes mellitus.
\end{abstract}

Keywords: reminiscence, art therapy, chronic disease, diabetes mellitus, elderly

Abstrak. Program Lansia Sabar yang disusun dari reminiscence dan terapi seni ditujukan untuk memfasilitasi lansia menilik kembali kehidupannya secara lebih positif. Program Lansia Sabar diikuti oleh sembilan lansia penyandang diabetes mellitus tipe II berusia 55-70 tahun yang mengalami kecemasan sedang hingga tinggi. Pengukuran tingkat kecemasan subjek dilakukan menggunakan skala Beck Anxiety Inventory (BAI). Program berlangsung selama enam pertemuan dengan durasi 120 menit tiap sesinya. Desain penelitian menggunakan one group pretest-posttest dengan double pretest. Analisis data kuantitatif menggunakan uji the friedman test, dilengkapi dengan analisis deskriptif terhadap hasil observasi, lembar kerja, dan visual inspection subjek. Hasil uji the friedman test menunjukkan $\mathrm{F}_{\mathrm{r}(2)}=5.200, \mathrm{p}=0.074$ ( $p>0.05)$. Hal ini menunjukkan Program Lansia Sabar tidak dapat menurunkan kecemasan pada lansia penyandang diabetes mellitus tipe II secara signifikan.

Kata kunci: reminiscence, terapi seni, penyakit kronis, diabetes melitus, lansia

\footnotetext{
${ }^{1}$ Korespondensi mengenai isi artikel dapat dilakukan melalui: errina.puspitasari@mail.ugm.ac.id

${ }^{2}$ Atau melalui sofi_53@yahoo.com
} 
Goldenberg \& Punthakee (2013), menyebutkan bahwa diabetes mellitus adalah penyakit yang menyerang metabolisme individu. Diabetes pada individu dapat memicu munculnya komplikasi penyakit lain seperti darah tinggi atau stroke. Oleh sebab itu disabilitas yang muncul pada penderita diabetes dapat merepresentasikan dampak kumulatif dari penyakit tersebut. Oleh sebab itu disabilitas yang muncul pada penderita diabetes dapat merepresentasikan dampak kumulatif dari penyakit tersebut. Berdasarkan penelitian Gregg \& Caspersen (2005), lansia yang mengalami diabetes mengalami kesulitan 2-3 kali lebih tinggi daripada lansia sehat untuk melakukan kegiatan fisik. Dari sisi psikologis Claude, Hadjistavropoulos \& Friesen (2014) menyebutkan bahwa lansia yang menderita diabetes cenderung mengalami kecemasan pada kesehatan mereka.

Berdasarkan Clark \& Beck (2010), kecemasan merupakan seperangkat respon kognitif, afektif, fisiologis, dan perilaku aktif ketika suatu peristiwa yang sudah diantisipasi ternyata dapat menyebabkan kesulitan. Di dalam DSM IV-TR (2000), dijelaskan lebih lanjut bahwa kecemasan dapat ditandai dengan gejala seperti gelisah/merasa tegang, merasa mudah lelah, sulit berkonsentrasi, mengalami ketegangan otot, menjadi kurang peka, dan mengalami gangguan tidur. Kecemasan dapat disebabkan oleh faktor biologis, psikologis dan sosial (Durand \& Barlow, 2006). Pishvaei, Moghanloo, \& Moghanloo (2015), menemukan bahwa salah satu isu penting dalam masa lansia adalah munculnya depresi maupun kecemasan. Kehilangan kekuatan, tujuan hidup, kemampuan fisik, penurunan kemampuan finansial dan adanya penyakit yang mematikan membuat lansia rentan mengalami depresi maupun kecemasan (Pishvaei, et al., 2015). Kecemasan yang dialami oleh lansia jika tidak ditangani dapat meningkatkan kemungkinan lansia tersebut mengalami permasalahan kesehatan lainnya seperti demensia (Zalik \& Zalar, 2013)

Poulsen, Pachana, \& McDermott (2014) menemukan bahwa kecemasan dan depresi banyak dialami oleh lansia penderita diabetes. Ketika individu mengetahui dirinya terkena penyakit, mereka cenderung berusaha untuk menjalankan pola hidup yang lebih sehat. Namun seiring usaha yang mereka lakukan ini juga muncul perasaan cemas dan khawatir dalam diri mereka, misalnya apakah makanan yang mereka konsumsi sudah tepat atau belum (Furer, Walker \& Stein, 2007)

Kondisi lansia penderita diabetes yang rentan terhadap permasalahan psikologis ini sesuai dengan keadaan yang ditemukan oleh peneliti selama melakukan Praktek Kerja Profesi Psikologi (PKPP) pada bulan JuliDesember 2015. Peneliti menemukan dari 10 lansia yang melakukan konsultasi psikologi, tiga diantaranya mengalami kecemasan pada kategori tinggi; lima 
lansia mengalami kecemasan pada kategori sedang; dua lansia mengalami kecemasan pada kategori rendah ketika diukur menggunakan BAI. Sayangnya kondisi psikologis lansia ini seringkali luput dari perhatian orang-orang yang ada di sekitarnya.

Salah satu terapi yang dapat digunakan untuk menangani kecemasan pada lansia secara umum maupun lansia dengan penyakit kronis adalah reminiscence dan terapi seni. Reminiscence merupakan proses mengingat kembali pengalaman-pengalaman yang terjadi dimasa lalu. Terapi ini pertama kali dikemukakan oleh Robert Butler seorang psikogeriatrik pada tahun 1960 (Haber, 2006). Dalam reminisence terdapat delapan fungsi yang dapat dicapai yaitu death preparation, identity, problem solving, teach/inform, conversation, boredom reduction, bitterness revival, dan intimacy maintenance (Webster dalam Westerhof \& Bohlmeijer, 2014).

Menurut Westerhof, Bohlmeijer, \& Webster (2010), proses menelaah kehidupan dapat dilakukan kepada lansia dengan permasalahan mental seperti depresi dan kecemasan. Tujuan dari terapi tersebut adalah memfasilitasi perubahan diri dan mengurangi simptom-simptom kondisi mental yang negatif. Hasil yang diharapkan dari rangkaian proses reminiscence adalah menurunnya tingkat depresi dan kecemasan pada klien (Webster, Bohlmeijer, \& Westerhof, 2010). Sesi reminisence yang dilakukan secara berkelompok dapat memotivasi lansia untuk berbagi pengalaman dan memori yang membentuk diri mereka hingga hari ini. Melalui proses tersebut, lansia dapat melakukan katarsis atas emosi-emosi yang dialaminya (Pishvaei, et al., 2015).

Fungsi reminisence sebagai terapi bagi lansia juga ditemukan pada terapi berbasis seni. Pada penelitian Kim (2013), ditemukan bahwa terdapat penurunan signifikan kecemasan yang dirasakan oleh lansia keturunan Korea-Amerika setelah mengikuti terapi kesenian. Setelah kegiatan terapi dilakukan muncul perasaan positif ketika para lansia ini saling mendengarkan dan dipahami tanpa adanya penilaian atau evaluasi. Peserta juga merasa berkesempatan untuk memperbarui ide, hobi dan kesempatan untuk belajar melalui seni.

Berdasarkan penelitian yang dilakukan oleh Ostrander (2012), penggunaan kombinasi reminiscence dan terapi seni lebih bermanfaat bagi klien lansia daripada bila digunakan secara terpisah. Kombinasi dari dua terapi ini memberikan kesempatan bagi lansia untuk mengembangkan proses kreatif dalam mengurangi permasalahan terkait kesehatan mental seperti kecemasan, depresi, dan well-being. Hal ini juga ditemukan dalam penelitian RavidHoresh (2004), yaitu adanya dampak positif dari sesi terapi seni dan reminiscence yang diberikan kepada lansia. Perbandingan antara gambar yang dibuat pada sesi satu dengan sesi terakhir memperlihatkan adanya perkembangan perspektif hidup lansia dari kekosongan menjadi perspektif kehidupan seimbang.

Dari uraian tersebut peneliti menyusun sebuah program yang merupakan gabungan dari reminisence dan terapi seni. Pada penelitian ini, bentuk terapi seni yang digunakan antara lain menggambar, mendengarkan musik, dan mengenang dengan foto kenangan. 
Tujuan disusunnya program ini adalah untuk untuk membantu menurunkan kecemasan yang dihadapi oleh lansia penderita diabetes melitus tipe II. Program ini kemudian disebut dengan nama "Program Lansia SABAR" (Sehat dan Bermakna). "Program Lansia SABAR" dirancang sebagai program integratif yang menggabungkan teknik terapi seni dalam proses menilik kembali kehidupan lansia. "Program Lansia SABAR" ini akan dilaksanakan sebanyak enam kali pertemuan dengan durasi per satu pertemuan selama maksimal 120 menit. Hipotesis dari penelitian ini adalah Program "Lansia Sabar" dapat menurunkan kecemasan pada lansia penderita diabetes mellitus tipe II.

\section{Metode}

Subjek

Subjek penelitian ini adalah sembilan orang lansia penyandang diabetes melitus tipe II. Berikut syarat partisipan penelitian ini (1) berusia 55-70 tahun; (2) didiagnosa secara medis mengidap penyakit diabetes melitus tipe II; (3) tidak mengalami disabilitas fisik seperti gangguan pendengaran dan penglihatan berat serta kelumpuhan; (4) masih mampu membaca dan menulis; (5) mampu memahami bahasa Indonesia; (6) masih tinggal bersama keluarga (pasangan/anak/saudara). Selanjutnya kriteria inklusi subjek ini adalah: (1) memiliki skor BAI (Beck Anxiety Inventory) sembilan tertinggi dari total subjek screening; (2) bersedia berpartisipasi dalam penelitian sesuai jangka waktu yang disepakati.
Alat dan materi

Modul "Program Lansia Sabar" (Sehat dan Bermakna)

Modul Program Lansia Sabar (Sehat dan Bermakna) merupakan modul yang disusun dari modifikasi reminiscence therapy dan terapi seni oleh Robert Butler (Haber, 2006); Ravid-Horesh (2004); (Malchiodi, 2003). Modul ini disusun oleh tim peneliti payung yang terdiri dari dua orang mahasiswa yaitu Errina Puspitasari dan Desak Ayu Wida Pratia Wijaya bersama dosen pembimbing. Modul ini memiliki koefisien validitas isi Aiken's V dengan rentang 0,750-0,950. Dengan demikian dapat disimpulkan bahwa modul Program Lansia Sabar memiliki validitas isi yang baik. Berdasarkan uji coba modul yang dilakukan terhadap lima orang lansia, ditemukan bahwa terdapat perbedaan signifikan skor skala cek manipulasi sebelum dan sesudah perlakuan. Dari uji wilcoxon signed ranks test terhadap cek manipulasi skala fungsi reminiscence diperoleh $Z=-2,023, p=0,043$ $(p<0,05)$. Kemudian dari hasil uji cek manipulasi skala terapi seni diperoleh $\mathrm{Z}=$ $-2,032, p=0,042(p<0,05)$

\section{Skala Beck Anxiety Inventory (BAI)}

Beck Anxiety Inventory merupakan skala yang dikembangkan untuk menilai tingkat kecemasan pada individu. Terdapat 21 aitem yang disusun berdasarkan tiga aspek yaitu: (1) kognitif; (2) afektif; (3) somatik (Beck, Brown, Epstein, \& Steer, 1988). BAI yang digunakan dalam penelitian ini adalah BAI berbahasa Indonesia yang disusun oleh Sasmitawati (2008). Pada penelitian ini uji reliabilitas dilakukan kembali terhadap 32 lansia. Berdasarkan hasil 
analisis diperoleh $\alpha=0,888$ dengan $\mathrm{r}_{\mathrm{ix}}=$ 0,255-0,655.

\section{Cek Manipulasi Skala Fungsi Reminiscence}

Skala ini dimodifikasi dari Reminiscence Functional Scale (RFS) yang disusun oleh (Webster, 1993). RFS digunakan untuk mengetahui fungsi dari reminiscence terhadap subjek dan sekaligus sebagai cek manipulasi pada penelitian ini. Berdasarkan perhitungan Aiken's V terhadap rating yang diberikan oleh 30 rater, diperoleh rentang $\mathrm{V}=0,608-0,825$. Hal ini menunjukkan bahwa koefisien validitas isi dari aitem skala tersebut relatif cukup baik. Selanjutnya, dari uji reliabilitas terhadap 32 lansia diperoleh $\alpha$ $=0,830$ dengan $\mathrm{r}_{\mathrm{ix}}=0,256-0,586$.

\section{Cek Manipulasi Terapi Seni}

Skala ini dibuat berdasarkan sesi terapi yang dilakukan terhadap partisipan. Berdasarkan Russel, 1974 (dalam Ahmad, Sulaiman, Abdullah, \& Shamsuddin, 2009), disebutkan bahwa aitem untuk mengetahui pemahaman subjek atas modul dapat disusun berdasarkan aktivitas dari modul tersebut. Berdasarkan perhitungan Aiken's $\mathrm{V}$ terhadap rating yang diberikan oleh 30 rater, diperoleh rentang $\mathrm{V}=0,700$ 0,825 . Hal ini menunjukkan bahwa koefisien validitas isi dari aitem skala tersebut relatif cukup baik. Selanjutnya, dari uji reliabilitas terhadap 38 lansia diperoleh $\alpha=0,770$ dengan $r_{\text {ix }}=0,370$ 0,572 .

Lembar observasi dan catatan lapangan Lembar ini terdiri atas lembar observasi terhadap subjek dan lembar catatan lapangan selama proses intervensi berlangsung. Pencatatan lembar observasi partisipan dan catatan lapangan ini akan dilakukan oleh observer.

\section{Lembar kerja subjek Program Lansia Sabar} Lembar kerja ini berisikan instruksi dan lembar untuk melakukan tugas selama proses terapi berlangsung.

\section{Catatan harian partisipan Program Lansia} Sabar

Catatan harian ini merupakan skala ukur diri yang berisikan simptom kecemasan harian dan keterangan kegiatan partisipan sebagai tugas rumah. Catatan harian ini diisi subjek setiap hari sejak pertemuan pertama Program Lansia Sabar hingga terakhir.

\section{Desain Penelitian}

Penelitian ini menggunakan metode penelitian quasi-experiment. Desain eksperimen yang digunakan adalah the one-group pretest-posttest design using a double pretest. Dua kali pretes pada desain ini berfungsi untuk memastikan bias yang mungkin muncul dan mempengaruhi efek perlakuan dari pretes kedua hingga posttes (Campbell \& Cronbach, 2002).

$\mathrm{O}_{1}$

$\mathrm{O}_{2} \quad \mathrm{X}$

$\mathrm{O}_{3}$

\section{Keterangan:}

$\mathrm{O}_{1}$ : Pretes 1 (screening awal)

$\mathrm{O}_{2}$ : Pretes 2

$\mathrm{O}_{3}$ : Posttes

Intervensi

Intervensi yang diberikan kepada subjek adalah Program Lansia Sabar (Sehat dan Bermakna). Program ini bertujuan untuk menurunkan kecemasan subjek melalui 
proses memaknai kembali pengalamannya di masa lalu secara lebih positif. Pada setiap pertemuan, subjek diminta mengenang kembali pengalamannya di masa (1) anak-anak; (2) remaja; (3) dewasa; (4) lansia. Program Lansia Sabar dilakukan selama enam pertemuan dalam bentuk terapi kelompok. Enam pertemuan dilakukan dalam rentang waktu tiga minggu dengan durasi tiap pertemuan 120 menit. Pelaksana intervensi yaitu: Satu orang fasilitator, psikolog klinis yang memiliki pengalaman penanganan klien lansia dan kelompok, satu orang co-fasilitator, mahasiswa magister psikologi profesi bidang klinis yang telah lulus ujian HIMPSI, dan dua orang observer, sarjana S1 psikologi yang menguasai metode observasi

\section{Analisis data}

Data yang diperoleh dalam penelitian ini akan dianalisis secara kuantitatif dan the Friedman test ; (2) analisis deskriptif dilakukan terhadap hasil observasi, diskusi, lembar kerja, dan catatan harian subjek.

Hasil
Analisis kuantitatif
Uji hipotesis dilakukan menggunakan the
Friedman test, uji non parametrik guna
melihat perbedaan skor pretest 1, pretest
2, dan posttest subjek. Berdasarkan uji the
Friedman test terhadap skor BAI 9 orang
subjek diperoleh hasil $\mathrm{F}_{\mathrm{r}(2)}=5,200, \mathrm{p}=$
0,074 ( $\mathrm{p}>0,05$ ). Hal ini menunjukkan
bahwa tidak ada perbedaan signifikan
antara skor BAI subjek pada pretest 1 ,
pretest 2, dan posttest. Oleh sebab itu
dapat disimpulkan bahwa Program
Lansia Sabar (Sehat dan Bermakna) tidak
dapat menurunkan kecemasan pada
lansia penyandang diabetes mellitus tipe
II. Berikut rangkuman skor BAI pretest 1
- posttest subjek Program Lansia Sabar.

\section{Analisis kuantitatif}

Uji hipotesis dilakukan menggunakan the Friedman test, uji non parametrik guna melihat perbedaan skor pretest 1, pretest 2, dan posttest subjek. Berdasarkan uji the Friedman test terhadap skor BAI 9 orang subjek diperoleh hasil $\mathrm{F}_{\mathrm{r}(2)}=5,200, \mathrm{p}=$ 0,074 ( $p>0,05$ ). Hal ini menunjukkan bahwa tidak ada perbedaan signifikan antara skor BAI subjek pada pretest 1, pretest 2, dan posttest. Oleh sebab itu dapat disimpulkan bahwa Program Lansia Sabar (Sehat dan Bermakna) tidak dapat menurunkan kecemasan pada lansia penyandang diabetes mellitus tipe - posttest subjek Program Lansia Sabar.

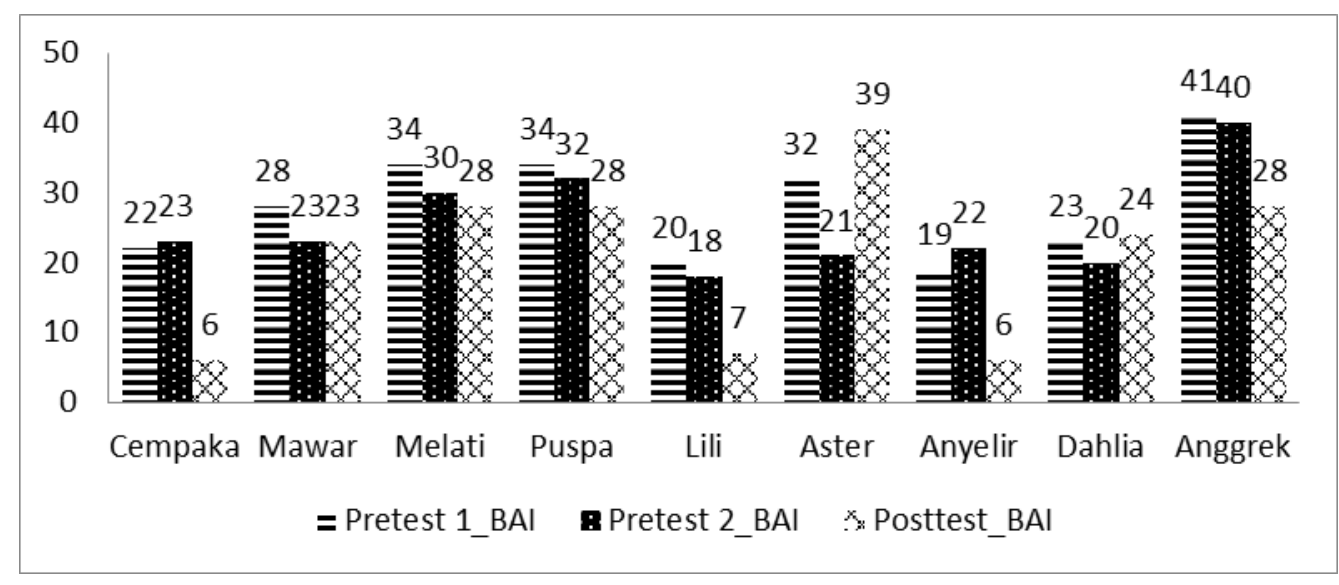

Grafik Perubahan Skor Beck Anxiety Inventory Pretest 1-Posttest

deskriptif; (1) analisis kuantitatif dilakukan terhadap hasil Beck Anxiety Inventory (BAI) pre-test 1, pre-test 2, dan post-test subjek program menggunakan
Uji cek manipulasi

Uji skala cek manipulasi dilakukan menggunakan wilcoxon signed rank test. Berdasarkan uji yang dilakukan pada 
skor pretest dan posttest skala cek manipulasi fungsi reminiscence, diperoleh $Z=-2,677, p=0,007$ ( $p<0,05)$. Hasil tersebut menunjukkan adanya perbedaan signifikan antara fungsi mengenang masa lalu sebelum subjek mendapat perlakuan dan sesudahnya. Selanjutnya, dari uji skala cek manipulasi terapi seni diperoleh $Z=-2,194, p=0,028(p<0,05)$. Hasil tersebut menunjukkan adanya perbedaan signifikan dalam fungsi kegiatan seni sebelum subjek mendapat perlakuan dan sesudahnya. Hal ini juga memperlihatkan bahwa program atau perlakuan yang diberikan telah tersampaikan secara tepat (Campbell \& Cronbach, 2002). Kondisi ini tidak lepas dari peran fasilitator dalam penelitian. Fasilitator mampu menyampaikan refleksi empati dan membantu subjek menemukan makna dibalik pengalaman yang kurang menyenangkan.

\section{Analisis tambahan}

Analisis skor Beck Anxiety Inventory (BAI) berdasarkan aspek

Berdasarkan uji the Friedman test, ditemukan bahwa aspek kognitif $\left(\mathrm{F}_{\mathrm{r}(2)}=\right.$ $7,517, \mathrm{p}=0,023)$ dan afektif $\left(\mathrm{F}_{\mathrm{r}(2)}=6,412, \mathrm{p}\right.$ $=0,041)$ merupakan aspek yang mengalami perubahan skor selama proses penelitian. Uji lanjutan dilakukan menggunakan wilcoxon signed rank test untuk mengetahui dimana letak skor yang mengalami perubahan signifikan. Pada aspek kognitif terjadi perubahan signifikan pada skor pretest 2-posttest ( $Z$ $=-2,456, \mathrm{p}=0,014)$; sementara pada aspek afektif terjadi perubahan signifikan pada skor pretest $1-2(Z=-2,328, p=0,020)$.

Analisis skor Beck Anxiety Inventory (BAI) berdasarkan status pernikahan subjek
Uji mann-whitney $u$ test dilakukan untuk membandingkan skor pretest hingga posttest BAI di antara dua kelompok subjek tersebut. Dari uji antara skor pretest 1 BAI subjek janda dan subjek menikah tampak adanya perbedaan skor kecemasan signifikan yang $(\mathrm{Z}=-2,334, \mathrm{p}=$ $0,024)$. Dari uji skor pretest 2 BAI subjek janda dan subjek menikah tampak tidak ada perbedaan skor kecemasan yang signifikan $(Z=-1,167, p=0,262)$. Uji yang dilakukan terhadap skor posttest BAI subjek janda dan menikah menunjukkan adanya perbedaan skor kecemasan yang signifikan $(Z=-2,374, p=0,024)$. Dari skor pretest 1 dan posttest subjek, tampak bahwa skor kecemasan subjek menikah lebih tinggi daripada skor kecemasan subjek janda.

\section{Analisis deskriptif}

Secara umum, sesi dalam Program Lansia Sabar berjalan dengan cukup lancar. Semua subjek bersedia mengikuti kegiatan sesuai dengan panduan dari fasilitator maupun co-fasilitator. Subjek mulai dapat saling terbuka dengan nyaman pada pertemuan ketiga, yaitu pada sesi yang membicarakan pengalaman masa remaja. Subjek juga dapat saling memberikan dukungan satu sama lain ketika menemukan pengalaman yang mirip. Hanya saja, masih ada subjek yang belum mampu terbuka sepenuhnya pada perasaannya yaitu subjek Aster. Selain itu, masih ada pula subjek yang kesulitan untuk menerima pengalaman buruknya dimasa lalu akibat kurang adekuatnya problem solving saat itu yaitu Puspa. Terkait status pernikahannya, subjek dengan status janda cenderung menceritakan 
pengalaman positif dan mampu mandiri sepeninggal pasangannya. Sementara, subjek dengan status menikah masih harus menghadapi isu pribadi dengan pasangannya. Contohnya adalah persoalan terkait perselingkuhan, masalah ekonomi, dan perawatan suami dengan gangguan jiwa.

Dari catatan harian, perubahan simptom kecemasan harian subjek ratarata terjadi bertepatan dengan aktivitas atau perasaan yang dirasakan subjek pada setiap harinya. Kejadian terkait; (1) kegiatan dengan cucu/keluarga; (2) kesibukan pekerjaan; (3) penyakit tidak kronis yang tidak kunjung sembuh terjadi bersamaan dengan penurunan/kenaikan simptom kecemasan harian subjek. Berdasarkan hasil diskusi dengan peserta pada pertemuan keenam, dapat disimpulkan beberapa hal yang mereka dapatkan selama program berlangsung. Peserta menyebutkan bahwa mereka : (1) memahami bahwa bukan dirinya sendiri yang memiliki masalah; (2) lebih memahami mengenai permasalahan yang sudah mereka lewati; (3) merasa lebih sabar; (4) dapat menghibur diri sendiri maupun orang lain; (4) merasa bahagia karena dapat berkumpul bersama teman dan lebih saling mengenal.

\section{Diskusi}

Hasil uji hipotesis penelitian ini sesuai dengan penelitian Haslam, Haslam, Ysseldyk, McCloskey, Pfisterer, \& Brown (2014) mengenai pengaruh reminiscence dan musik terhadap kecemasan lansia. Pada penelitian yang dilakukan terhadap 40 lansia, tidak ditemukan adanya pengaruh signifikan atas pemberian terapi reminiscence terhadap kecemasan subjek. Dalam penelitian ini, ditemukan bahwa faktor yang mempengaruhi hasil uji efektivitas reminiscence salah satunya adalah identifikasi sosial. Menurut Haslam et al., (2014), identifikasi sosial mengacu pada rasa kepemilikan subjek terhadap kelompok reminiscencenya.

Pada prosesnya, belum semua subjek Program Lansia Sabar mengembangkan rasa kepemilikan terhadap kelompoknya. Terdapat satu orang, yaitu subjek Aster yang masih belum mampu sepenuhnya terbuka dalam menceritakan pengalamannya. Sesuai dengan penelitian Haslam, et al. (2014), proses reminiscence hanya dapat menjadi efektif ketika subjek dapat berbagi pengalaman hidupnya kepada teman kelompoknya.

Di samping masalah identifikasi sosial, dalam Program Lansia Sabar ini juga masih ada subjek yang tampak sulit melepaskan kenangan pahitnya yaitu subjek Puspa. Selama ini Puspa belum bisa menunjukkan suatu problem solving yang cukup memuaskan dirinya. Dalam proses terapi pun, Puspa membutuhkan bantuan dari fasilitator untuk bisa menemukan makna atas pengalamannya. Sesuai dengan penelitian O'Rourke, Cappeliez, \& Claxton (2011), mengenang suatu pengalaman negatif secara terus menerus dapat menjadi suatu pertanda yang negatif pula. Kondisi ini menunjukkan bahwa individu masih terikat pada permasalahan yang terjadi dimasa tersebut.

Sementara itu, dari sembilan subjek terdapat tiga kelompok perubahan terkait skor kecemasan yaitu (1) subjek yang relatif mengalami penurunan skor kecemasan; (2) subjek yang relatif 
memiliki skor kecemasan tetap; (3) subjek yang relatif mengalami kenaikan skor kecemasan. Subjek yang mengalami penurunan skor kecemasan terbesar adalah Cempaka yaitu sebesar 17 poin dari pretest 2 ke posttest. Hal ini dapat terjadi karena Cempaka cukup mampu memaknai pengalaman yang sudah dihadapinya secara positif. Ia juga mampu mengingat strategi problem solving yang cukup memuaskan dirinya dalam melewati permasalahan hidup. Kondisi yang dicapai oleh Cempaka ini menunjukkan bahwa dirinya telah mencapai tujuan dari proses reminiscence yaitu penerimaan diri (Webster, Bohlmeijer, \& Westerhof, 2010).

Selanjutnya, subjek yang memiliki skor relatif tetap sejak pretest 1 hingga posttest adalah Dahlia. Hal ini tidak terlepas dari kondisi pribadi Dahlia yang disadarinya. Secara afektif Dahlia mengutarakan bahwa dirinya cukup sensitif ketika teringat pengalamannya di masa lalu. Oleh sebab itu, tampak beberapa kali Dahlia menangis saat bercerita. Sesuai dengan konsep biologis kecemasan, ketika individu menerima suatu stimulus yang mengancam maka bagian sistem saraf simpatik menjadi aktif. Kejadian ini menyebabkan terjadinya hyperarousal symptoms dan tampak sebagai gejala fisiologis seperti jantung berdebar, mulut kering, dll (Clark \& Beck, 2010).

Aster adalah subjek yang mengalami kenaikan skor kecemasan sebanyak 18 poin pada pretest 2 ke posttest. Selama mengikuti Program Lansia Sabar, Aster sering menolak ketika diminta bercerita pada urutan awal. Oleh sebab itu, seringkali Aster menjadi subjek terakhir yang bercerita. Padahal sesuai dengan penelitian Haslam, dkk (2014), proses reminiscence hanya dapat menjadi efektif ketika subjek berbagi pengalaman hidupnya kepada teman kelompoknya.

Selanjutnya dari hasil analisis tambahan tampak terjadi penurunan signifikan skor BAI aspek kognitif pretest 2-posttest subjek. Hal ini terkait dengan proses reminiscence yang membutuhkan kegiatan kognitif. O'Rourke, Cappeliez, \& Claxton (2011), menyebutkan bahwa proses mengingat cara-cara memecahkan masalah secara sukses dapat mempertegas kembali persepsi subjek pada kemampuannya. Keberhasilan koping dimasa lalu terhadap kesulitan hidup akan memperkuat kepercayaan subjek untuk mengatasi kesulitan saat ini. Sementara itu penurunan signifikan skor BAI aspek afektif yang terjadi pada pretest 1-2 subjek kemungkinan terjadi sebagai akibat dari efek history, yaitu segala kejadian yang muncul selama penelitian berlangsung. Kejadian ini terkait dengan peristiwa sehari-hari yang dapat memberikan pengaruh pada subjek tanpa adanya perlakuan terhadap mereka (Campbell \& Cronbach, 2002). Kondisi ini juga dapat menjelaskan adanya perubahan skor catatan harian subjek ketika mereka mengalami suatu kondisi tertentu. Dari hasil analisis individual, kondisi seperti (1) kegiatan dengan cucu/keluarga; (2) kesibukan pekerjaan; (3) penyakit tidak kronis yang tidak kunjung sembuh terjadi bersamaan dengan penurunan/kenaikan simptom kecemasan harian subjek.

Pada analisis yang dilakukan terhadap skor kecemasan subjek berdasarkan status pernikahannya ditemukan pula adanya perbedaan. Secara skor dan kategori, tingkat 
kecemasan subjek berstatus janda relatif lebih rendah daripada subjek berstatus menikah. Berdasarkan Carr, House, Kessler, Nesse, Sonnega, \& Wortman (2000), kematian pasangan di masa lansia sebenarnya adalah prediktor yang signifikan atas munculnya depresi atau kecemasan. Kematian pasangan ini dapat menimbulkan suatu kecemasan bagi janda bila terkait dengan perubahan besar dalam tanggung jawab dan beban sehari-hari. Tingkat kecemasan pada janda dapat menjadi beragam tergantung pada seberapa tergantung individu pada pasangannya (Carr, House, Kessler, Nesse, Sonnega, \& Wortman, 2000). Penelitian tersebut sesuai dengan kondisi subjek Program Lansia Sabar, subjek janda cenderung dapat hidup secara mandiri sepeninggal suaminya. Di sisi lain, subjek menikah masih perlu menghadapi tantangan dan pengalaman rumah tangga yang tidak terlalu positif. Sesuai dengan penelitian Bulanda, Brown, \& Yamashita (2016), pada wanita kualitas interaksi yang rendah dalam pernikahan dapat menimbulkan dampak negatif. Pernikahan yang tidak bahagia dapat menjadi sumber stres berkepanjangan dan memperburuk kondisi kesehatan.

Meskipun secara statistika Program Lansia Sabar tidak dapat menurunkan kecemasan subjek, masih ada hal yang mereka dapatkan. Dari analisis deskriptif, subjek menyebutkan bahwa mereka : (1) memahami bahwa bukan dirinya sendiri yang memiliki masalah; (2) lebih memahami mengenai permasalahan yang sudah mereka lewati; (3) merasa lebih sabar; (4) dapat menghibur diri sendiri maupun orang lain; (5) merasa bahagia karena dapat berkumpul bersama teman dan lebih saling mengenal. Manfaat yang dirasakan subjek tidak terlepas dari proses terapi secara berkelompok.

Hal ini sesuai dengan penelitian Pishvaei, Moghanloo, \& Moghanloo (2015), bahwa proses reminiscence secara berkelompok membantu subjek berbagi pengalaman yang membentuk diri mereka. Kondisi ini membuat subjek mampu mengembangkan identitas dan menegaskan kembali arti hidup mereka. Melalui penelitian ini, subjek menjadi lebih sadar bahwa orang yang mengalami kesulitan bukan hanya diri mereka seorang. Hal ini sesuai dengan manfaat universality (Yalom \& Leszcz, 2005). Proses selanjutnya, subjek juga saling berganti peran untuk menyemangati dan menerima semangat dari satu sama lain. Sesuai kondisi ini, subjek telah menerima manfaat altruism (Yalom \& Leszcz, 2005). Manfaat ini, pada sesi lima khususnya, terlihat sangat jelas ketika para peserta saling mendukung dalam menjaga kesehatan terkait penyakit diabetes mereka. Hal ini sesuai dengan penelitian Koetsenruijter, Eikelenboom, Lieshout, Vassilev, Lionis, Todorova, et al. (2016), bahwa dukungan emosi dan sosial dari orang-orang di sekitar penderita diabetes dapat memberikan manfaat pada kemampuan manajemen diri mereka.

Peserta juga melakukan immitative behavior dengan mengambil hal yang bisa dipelajari dari pengalaman peserta lain (Yalom \& Leszcz, 2005). Kemudian dari setiap pertemuan terapi, peserta juga mendapatkan kesempatan untuk melakukan katarsis atas permasalahan yang dihadapi. Peran fasilitator juga turut memberikan manfaat melalui instillation hope. Fasilitator memberikan rasa nyaman dan memfasilitasi terbentuknya 
pandangan positif subjek atas pengalamannya maupun pengalaman anggota kelompok secara keseluruhan (Yalom \& Leszcz, 2005).

Kegiatan yang menggunakan seni sebagai media pengingat juga cukup membantu subjek memaparkan pengalamannya. Hal ini sesuai dengan penelitian Sato (2011), penggunaan lebih dari satu stimulus membantu individu lebih mudah dalam mengingat kenangan mereka. Proses seni yang dilakukan oleh subjek mampu membantu mereka mengingat perasaan yang selama ini belum disampaikan. Hal ini memfasilitasi subjek untuk bisa lebih memahami diri dan bagaimana mereka terhubung dengan orang-orang di sekitarnya (Farokhi, 2011).

Penelitian ini masih memiliki keterbatasan dalam prosesnya. Peneliti telah menggunakan desain eksperimen dengan dua kali pretest untuk meminimalisasi ancaman validitas internal penelitian. Meskipun begitu, ancaman tersebut masih tetap ada yaitu ancaman history dan testing.

\section{Kesimpulan}

Berdasarkan analisis yang telah dilakukan dapat disimpulkan bahwa Program Lansia Sabar berbasis reminiscence dan terapi seni tidak dapat menurunkan kecemasan pada lansia penyandang diabetes mellitus tipe II. Dari analisis tambahan, disimpulkan bahwa aspek kognitif terkait kecemasan pada subjek mengalami perubahan signifikan selama penelitian berlangsung. Hal ini tidak lepas dari kegiatan reminiscence yang membutuhkan evaluasi secara kognitif atas pengalaman subjek dalam memandang masa lalunya. Sementara itu dari status pernikahannya, lansia dengan status janda memiliki tingkat kecemasan lebih rendah daripada lansia menikah.

\section{Saran}

Bagi subjek, disarankan dapat melakukan kegiatan-kegiatan yang telah ditemukan selama penelitian untuk mengisi waktu secara positif. Misalnya dengan melakukan hobi positif yang disukai seperti menyanyi atau bercocok tanam.

Bagi Puskesmas, melalui tenaga psikolog Puskesmas, diharapkan dapat membentuk layanan psikologis dengan pendekatan kelompok. Program secara berkelompok perlu dilakukan dengan dipandu oleh psikolog Puskesmas secara rutin.

Bagi peneliti selanjutnya, disarankan untuk mengembangkan cakupan penelitian ini misalnya dengan melibatkan subjek dengan karakteristik lain. Bila memungkinkan, peneliti selanjutnya dapat menambah jumlah subjek penelitian dan menggunakan desain eksperimen untreated control group design.

\section{Kepustakaan}

Ahmad, J., Sulaiman, T., Abdullah, S. K., \& Shamsuddin, J. (2009). Building a customized module for the treatment of drug addiction under the remedial programs to be implemented on inmates at the drug rehabilitation centers in Malaysia. US-China Education Review, 6(11), 57-64.

American Psychiatric Association. (2000). Diagnostic and statistical manual of mental disorders fourth edition text revision, DSM-IV-TR. Arlington, 
VA: American Psychiatric Association.

Beck, A. T., Brown, G., Epstein, N., \& Steer, R. A. (1988). An inventory for measuring clinical anxiety: Psychometric properties. Journal of Consulting and Clinical Psychology, 56(6), 893-897.

Bulanda, J. R., Brown, S. J., \& Yamashita, T. (2016). Marital quality, marital dissolution, and mortality risk during the later. Journal of Social Science \& Medicine, 165, 119-127.

Campbell, D. T., \& Cronbach, L. J. (2002). Experimental and quasi-experimental designs for generalized causal inference. Boston: Houghton Mifflin Company.

Carr, D., House, J. S., Kessler, R. C., Nesse, R. M., Sonnega, J., \& Wortman, C. (2000). Marital quality and psychological adjustment to. Journal of Gerontology: Social Sciences, 55B(4), 197-207.

Clark, D. A., \& Beck, A. T. (2010). Cognitive therapy of anxiety disorders: Science and practice. New York: Guilford Press.

Claude, J. A., Hadjistavropoulos, H. D., \& Friesen, L. (2014). Exploration of health anxiety among individuals with diabetes: Prevalence and implications. Journal of Health Psychology, 19(2), 312-322.

Durand, M. V., \& Barlow, D. H. (2006). Psikologi abnormal. (H. P. Soetjipto, \& S. M. Soetjipto, Penerj.) Yogyakarta: Pustaka Pelajar.

Furer, P., Walker, J. R., \& Stein, M. B. (2007). Treating health anxiety and fear of death. New York: Springer Science+Business Media.
Gregg, E. W., \& Caspersen, C. J. (2005). Physical disability and the cumulative impact of diabetes in older adults. The British Journal of Diabetes and Vascular Disease, 5(1), 13-17.

Goldenberg, R., \& Punthakee, Z. (2013). Definition, classification, and diagnosis of diabetes, prediabetes, and metabolic syndrome. Canadian Journal of Diabetes, 8-11.

Haber, D. (2006). Life review: Implementation, theory, research and therapy. International journal aging and human development, 63(2), 153-171.

Haslam, C., Haslam, A., Ysseldyk, R., McCloskey, L.-G., Pfisterer, K., \& Brown, S. G. (2014). Social identification moderates cognitive health and well-being following story- and song-based. Journal of Aging \& Mental Health, 18(4), 425434.

Kelly, C. G., Cudney, S., \& Weinert, C. (2012). Use of creative arts as a complementary therapy by rural women coping with chronic illness. Journal of Holistic Nursing, 30(1), 48-54.

Koetsenruijter, J., Eikelenboom, N. v., Lieshout, J. v., Vassilev, I., Lionis, C., Todorova,E., et al. (2016). Social support and selfmanagement capabilities in diabetes patients: An international observational study. Journal of Patient and Counseling, 90, 636-643.

Kim, S. K. (2013). A randomized, controlled study of the effects of art therapy on older KoreanAmerican's healthy aging. The arts of psychotherapy, 40, 158-164. 
Malchiodi, C. A. (2003). Handbook of art therapy. New York: The Guilford Press.

Ostrander, A. (2012). Integrating reminiscence therapy and expressive art therapy as a treatment technique for working with the elderly. Disertasi. (tidak dipublikasikan). Saybrook University, California.

O'Rourke, N., Cappeliez, P., \& Claxton, A. (2011). Functions of reminiscence and the psychological well-being of young-old and older. Journal of Aging \& Mental Health, 15(2), 272281.

Pishvaei, M., Moghanloo, R. A., \& Moghanloo, V. A. (2015). The efficacy of treatment reminders of life with emphasis on integrative reminiscence on self-esteem and anxiety in widowed old men. Iran Journal of Psychiatry, 10(1), 19-24.

Poulsen, K. M., Pachana, N. A., \& McDermott, B. M. (2014). Health professionals, detection of depression and anxiety $\mathrm{n}$ their patients with diabetes: The influence of patient, illness and psychological factors. Journal of Health Psychology, 1-10.

Ravid-Horesh, R. (2004). "A temporary guest": The use of art therapy in life review with an elderly woman. The Arts in Psychotherapy, 31, 303-319.
Sasmitawati, T. A. (2008). Terapi kognitif perilakuan untuk mengurangi kecemasan pada penderita asma. Tesis. (tidak dipublikasikan). Universitas Gadjah Mada, Yogyakarta

Sato, Y. (2011). Musical life review in hospice. Music Therapy Perspectives, 29, 31-38

Webster, J. D. (1993). Construction and Validation of the Reminiscence Functions Scale. Journal of Gerontology: Psychological Sciences, 48(5), 256-262.

Webster, J. D., Bohlmeijer, E. T., \& Westerhof, G. J. (2010). Mapping the future of reminiscence: A conceptual guide for research and practice. Research on Aging, 32(4), 527-564.

Westerhof, G. J., \& Bohlmeijer, E. T. (2014). Celebrating fifty years of research and applications in reminisence and life review: State of the art and new directions. Journal of Aging Studies, 29, 107114.

Yalom, I., \& Leszcz, M. (2005). The theory and practice of gorup psychotherapy. New York: Basic Books.

Zalik, E., \& Zalar, B. (2013). Difference in mood between ederly persons living in different residential environments in Slovenia. Psychiatria Danubina, 25(1), 40-48. 